\title{
Studies of fatty liver and kidney syndrome in chickens: dynamics of glucose metabolism
}

\author{
By D. BALNAVE*, J. WOLFENDEN, F. M. BALL, R. B. CUMMING \\ AND R. A. LENG \\ Department of Biochemistry and Nutrition, University of New England, Armidale, \\ N.S.W. 2351, Australia
}

(Received 16 June 1976 - Accepted 4 January 1977)

\begin{abstract}
1. Fatty liver and kidney syndrome (FLKS) was induced in a proportion of a group of 4-week-old chickens by giving a diet of meat meal and wheat; inclusion in the diet of animal tallow for $54 \mathrm{~h}$ substantially reduced the occurrence of FLKS.

2. Measurements of dynamic aspects of glucose metabolism were made with single injections of [2-3'H]glucose which indicated that birds given the 'FLKS-inducing' diet and showing physical symptoms of FLKS had significantly lower rates of synthesis of glucose than birds given either the same diet supplemented with tallow or a commercial diet.

3. In a second series of experiments glucose metabolism was studied in birds (1) with or without physical symptoms that were given the 'FLKS-inducing' diet and (2) birds given the same diet supplemented with tallow or biotin. Affected birds fed the 'FLKS-inducing' diet had significantly lower plasma glucose concentrations, pool sizes and synthesis rates than birds fed the same diet and not showing symptoms, or birds fed the supplemented diets.

4. It is suggested that the cause of death in birds with FLKS is a low rate of gluconeogenesis during periods without feed which results in a lack of glucose to meet essential functions.
\end{abstract}

Fatty liver and kidney syndrome (FLKS) is a condition that occurs in growing chickens during the first few weeks of life. Mortality can be high and the syndrome has been characterized by a low blood glucose level which has led to suggestions that death is caused by a lack of glucose for essential functions (Evans \& Bannister, 1974). This is supported by studies in affected birds which indicate that some of the enzymes of gluconeogenesis in the liver are low (see p. 329). Since the recognition that the condition is responsive to biotin supplementation (Payne, Gilchrist, Pearson \& Hemsley, 1974; Whitehead, Bannister, Wight \& Weiser, 1974) studies have concentrated on the biotin-dependent enzymes. In the livers of birds suffering from FLKS the specific activity of the biotin-dependent enzyme pyruvate carboxylase [EC 6.4.1.1] is decreased and that of acetyl CoA carboxylase [EC 6.4.1.2] increased (Bannister, 1976; Balnave, Cumming \& Sutherland, 1976; Johnson, Hood, Pearson \& Fogerty, 1976). In addition the gluconeogenic enzyme fructose-1,6diphosphate 1-phosphohydrolase [EC 3.1.3.11] is decreased (Balnave et al. 1976; Balnave \& Pearce, 1976). Glucose synthesis in liver slices from birds affected with FLKS has been shown also to be reduced when compared with those from control birds (Evans \& Bannister, 1974; Bannister, Evans \& Whitehead, 1975). However, extrapolation from liver enzyme specific activities or from in vitro slice techniques do not necessarily indicate reduced gluconeogenesis in affected birds.

In the studies presented here, glucose synthesis rates have been examined in intact birds using isotope dilution techniques which demonstrate that during starvation gluconeogenesis in FLKS-affected birds is approximately half that in non-affected birds of the same weight treated in the same way.

* Present address: New South Wales Department of Agriculture, Poultry Research Station, Seven Hills, Sydney, NSW 2147, Australia. 


\section{MATERIALS AND METHODS}

Experimental birds

One-d-old broiler female chickens were obtained from a commercial hatchery (Allied Genetic Breeders, Sydney, N.S.W.). They were maintained on a diet of crushed wheat for $4 \mathrm{~d}$ and then randomly divided into two groups and given either a diet based on wheat and meat meal (diet A) that is known to produce FLKS in growing broiler chickens (Payne et al. 1974) or a commercial diet (diet B). These diets contained 110 and $220 \mu \mathrm{g}$ biotin $/ \mathrm{kg}$ diet respectively. The birds were fed ad lib. throughout and had free access to water. They were maintained under controlled environmental conditions. Symptoms of FLKS were first noticed in the birds given diet A at about 3 weeks of age but no experiments on glucose synthesis were commenced until the birds were at least 4 weeks old.

Expt 1. Birds were subjected to the above treatment and at $28 \mathrm{~d}$ a group of birds on diet A were supplemented with $15 \%(\mathrm{w} / \mathrm{w})$ animal tallow in the diet for $54 \mathrm{~h}$. Measurements of glucose metabolism were then made following either 8 or $18 \mathrm{~h}$ without food. Since the birds given diet A and showing symptoms of FLKS after only $8 \mathrm{~h}$ of fast tended to have relatively low body-weights compared with the treatment mean, birds with low body-weights were selected for comparative purposes from those given diet $\mathrm{B}$. This problem was not encountered with birds fasted for $18 \mathrm{~h}$.

Expt 2. Experimental birds were given diet $\mathrm{A}$ from $4 \mathrm{~d}$ of age and at $28 \mathrm{~d}$ some were given this diet supplemented with biotin $(300 \mu \mathrm{g} / \mathrm{kg} \mathrm{diet})$ and from $33 \mathrm{~d}$ some of the remaining birds were given diet A supplemented with $15 \%(\mathrm{w} / \mathrm{w})$ animal tallow for $54 \mathrm{~h}$. Measurements of glucose synthesis rates were made on day 35 following an $8 \mathrm{~h}$ period without food.

\section{Measurements of dynamic aspects of glucose metabolism}

Since not all the birds given diet A developed FLKS those birds showing physical signs of FLKS (Classes 3 to 5; Whitehead, 1975) were identified before injection of labelled glucose; they were killed after the last blood sample was taken and the presence of FLKS confirmed by post-mortem examination (Whitehead, 1975). Studies of glucose metabolism were made by injecting into the wing vein $20 \mu \mathrm{Ci}, 1 \mathrm{mg}$ of $\left[2{ }^{3} \mathrm{H}\right]$ glucose (Radiochemical Centre, Amersham, Bucks.) in $1 \mathrm{ml}$ water. Samples of blood (3 or 4) were taken by syringe and heparinized needle from the jugular vein $10,20,30$ and 40 min post-injection.

\section{Calculations}

All criteria of glucose metabolism were calculated from isotope dilution curves according to first-order kinetics (Leng, 1970; Judson \& Leng, 1972).

\section{Chemical methods}

Blood samples $(1.5 \mathrm{ml})$ taken from the birds were cooled in ice and then centrifuged at $3000 \mathrm{~g}$ for $20 \mathrm{~min}$. Plasma was removed and stored at $-20^{\circ}$ before analysis. A known quantity of plasma (approx. $1 \mathrm{ml}$ ) was diluted with $4 \mathrm{ml}$ water, $2 \mathrm{ml}$ of this was taken and, following addition of carrier glucose, was used to produce the penta-acetate derivative for assay of radioactivity (see Jones, 1965) in a scintillation counter (Model 3320 Packard Instruments Co. Ltd). The remaining solution was used to assay glucose concentration by the glucose oxidase technique of Huggett \& Nixon (1957) using a Technicon Autoanalyser.

\section{RESULTS}

Occurrence of FLKS. The number of deaths resulting from FLKS in all groups of birds in Expts 1 and 2 are shown in Table 1. 
Table 1. Number of deaths and mean body-weights of chickens used for glucose studies in Expts 1 and 2*

\begin{tabular}{|c|c|c|c|c|c|}
\hline $\begin{array}{c}\text { Expt } \\
\text { no. }\end{array}$ & $\begin{array}{l}\text { Length of } \\
\text { starvation } \\
\text { period (h) }\end{array}$ & Diet & $\begin{array}{l}\text { Mean body- } \\
\text { weight (g) }\end{array}$ & $\begin{array}{l}\text { No. of } \\
\text { birds }\end{array}$ & $\begin{array}{l}\text { No. of } \\
\text { deaths }\end{array}$ \\
\hline 1 & $\begin{array}{r}8 \\
18 \\
18 \\
8 \\
18\end{array}$ & $\begin{array}{l}\mathrm{A} \\
\mathrm{A} \\
\mathrm{A}+\text { tallow } \\
\mathrm{B} \\
\mathrm{B}\end{array}$ & $\left.\begin{array}{l}170 \\
237\end{array}\right\}$ & $\begin{array}{l}30 \\
30 \\
30\end{array}$ & $\begin{array}{r}11 \\
3 \\
2\end{array}$ \\
\hline 2 & 8 & $\begin{array}{l}\text { A (birds with FLKS) } \\
\text { A (birds without FLKS) } \\
\text { A + tallow } \\
\text { A + biotin }\end{array}$ & $\left.\begin{array}{l}\left.\begin{array}{l}321 \\
317\end{array}\right\} \\
318 \\
334\end{array}\right\}$ & $\begin{array}{l}35 \\
20 \\
20\end{array}$ & $\begin{array}{l}7 \\
- \\
-\end{array}$ \\
\hline
\end{tabular}

* For details, see p. 330.

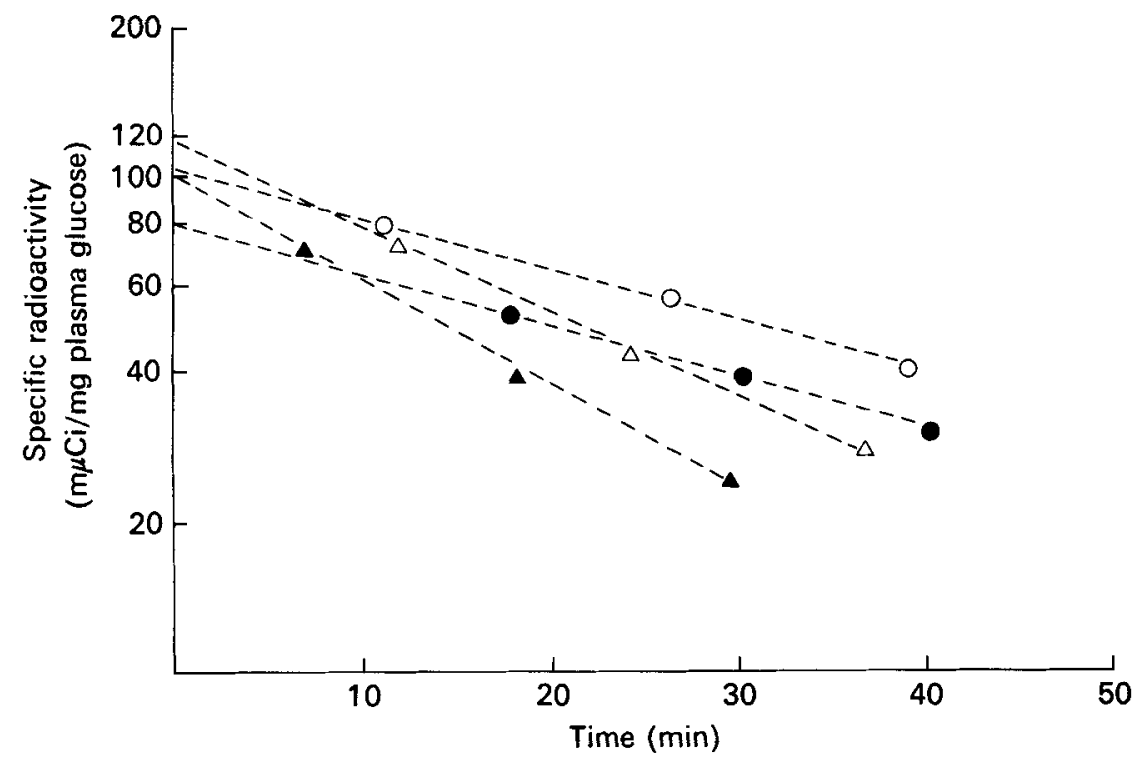

Fig. 1. The change in specific radioactivity of plasma glucose with time in birds following injection of $20 \mu \mathrm{Ci}\left[2-{ }^{3} \mathrm{H}\right] \mathrm{glucose}$ intravenously: (O) birds with FLKS on diet A, (O) birds without FLKS symptoms on diet $\mathbf{A},(\triangle)$ birds on diet $\mathbf{A}$ supplemented with tallow, $(\mathbf{A})$ birds on diet $\mathbf{A}$ supplemented with biotin.

Isotope dilution curves. A single exponential function described the relationship between specific radioactivity of plasma glucose with time after a single injection of radioactive glucose. Typical results from Expt 2 for a bird from all treatments are shown in Fig. 1.

Kinetics of glucose metabolism. The results for Expts 1 and 2 are given in Tables 2 and 3 respectively. Birds on diet A were selected for studies on glucose metabolism, depending on whether they were clinically normal or showed symptoms of FLKS after $8 \mathrm{~h}$ starvation.

In both experiments birds suffering from FLKS on diet $A$ and starved for $8 \mathrm{~h}$ had significantly lower plasma glucose levels, glucose pool sizes and rates of synthesis of glucose compared with birds without symptoms on the same diet or on diet B (Tables 2 and 3). Similar trends were observed after $18 \mathrm{~h}$ starvation but differences were not always 
Table 2. The effect on the dynamics of glucose metabolism in birds of feeding a 'FLKS-inducing' $\operatorname{diet}(\operatorname{diet} A)$, diet $A$ supplemented with animal tallow or a commercial diet (diet $B$ ). Birds were without feed for 8 or $18 \mathrm{~h}$

\begin{tabular}{|c|c|c|c|c|c|c|c|c|}
\hline Diet & $\begin{array}{l}\text { No. of } \\
\text { birds }\end{array}$ & $\begin{array}{r}\text { Symptoms } \\
\text { of FLKS }\end{array}$ & $\begin{array}{l}\text { Body- } \\
\text { weight } \\
\text { (g) }\end{array}$ & $\begin{array}{c}\text { Plasma } \\
\text { glucose } \\
(\mathrm{mg} / 100 \\
\mathrm{ml})\end{array}$ & $\begin{array}{c}\text { Plasma } \\
\text { glucose } \\
\text { half-time } \\
\text { (min) }\end{array}$ & $\begin{array}{c}\text { Glucose } \\
\text { pool } \\
\text { size } \\
\text { (mg) }\end{array}$ & $\begin{array}{c}\text { Glucose } \\
\text { pool } \\
\text { size } \\
(\mathrm{mg} / \mathrm{kg})\end{array}$ & $\begin{array}{c}\text { Glucose } \\
\text { synthesis } \\
\text { rate } \\
\text { (mg/min per } \\
\left.\mathrm{kg}^{0.75}\right)\end{array}$ \\
\hline \multicolumn{9}{|l|}{8 h starvation } \\
\hline $\begin{array}{l}\text { A } \\
\text { B } \\
\text { SEM }\end{array}$ & $\begin{array}{l}7 \\
7\end{array}$ & \pm & $\begin{array}{l}170 \\
260\end{array}$ & $\begin{array}{l}168 \\
258^{*} \\
27 \cdot 0\end{array}$ & $\begin{array}{l}20 \\
15^{*} \\
1 \cdot 6\end{array}$ & $\begin{array}{c}77 \\
206^{* * *} \\
14 \cdot 7\end{array}$ & $\begin{array}{c}474 \\
792^{* * *} \\
65 \cdot 4\end{array}$ & $\begin{array}{c}8 \cdot 0 \\
15 \cdot 6^{* * *} \\
1.0\end{array}$ \\
\hline \multicolumn{9}{|l|}{18 h starvation } \\
\hline $\begin{array}{l}\mathrm{A} \\
\mathrm{A}+\text { tallow } \\
\mathrm{B} \\
\mathrm{SEM}\end{array}$ & $\begin{array}{l}3 \\
3 \\
3\end{array}$ & $\begin{array}{l}+ \\
- \\
-\end{array}$ & $\begin{array}{l}237 \\
312 \\
438\end{array}$ & $\begin{array}{l}148 \\
292^{*} \\
218 \\
41 \cdot 3\end{array}$ & $\begin{array}{l}30 \\
16^{*} \\
16^{*} \\
3 \cdot 4\end{array}$ & $\begin{array}{l}108 \\
279^{*} \\
259^{*} \\
32 \cdot 0\end{array}$ & $\begin{array}{l}468 \\
903^{*} \\
582 \\
93 \cdot 3\end{array}$ & $\begin{array}{r}6.5 \\
13.7 \\
11.6 \\
2.8\end{array}$ \\
\hline
\end{tabular}

Table 3. The effect on the dynamics of glucose metabolism in birds of feeding a 'FLKS-inducing' diet (diet $A)$ and of supplementation of this diet with animal tallow or biotin

\begin{tabular}{|c|c|c|c|c|c|c|c|c|}
\hline Diet & $\begin{array}{l}\text { No. of } \\
\text { birds }\end{array}$ & $\begin{array}{l}\text { Symptoms } \\
\text { of FLKS }\end{array}$ & $\begin{array}{c}\text { Body- } \\
\text { weight } \\
\text { (g) }\end{array}$ & $\begin{array}{c}\text { Plasma } \\
\text { glucose } \\
(\mathrm{mg} / 100 \\
\mathrm{ml})\end{array}$ & $\begin{array}{l}\text { Plasma } \\
\text { glucose } \\
\text { half-time } \\
\text { (min) }\end{array}$ & $\begin{array}{c}\text { Glucose } \\
\text { pool } \\
\text { size } \\
\text { (mg) }\end{array}$ & $\begin{array}{l}\text { Glucose } \\
\text { pool } \\
\text { size } \\
(\mathrm{mg} / \mathrm{kg})\end{array}$ & $\begin{array}{c}\text { Glucose } \\
\text { synthesis } \\
\text { rate } \\
\text { (mg/min per } \\
\mathrm{kg}^{\mathbf{0} 75} \text { ) }\end{array}$ \\
\hline A & 5 & + & 321 & 148 & 25 & 130 & 383 & 6.4 \\
\hline & 5 & - & 3 & *** & 2 & **** & *** & $10 \cdot 1^{* * *}$ \\
\hline & 5 & - & 31 & $251^{* * *}$ & 21 & $231^{* *}$ & $724^{* * *}$ & $10 \cdot 7^{* * *}$ \\
\hline $\mathrm{A}+$ biotin & 5 & - & 334 & $230^{* * *}$ & $16^{* * *}$ & $219^{*}$ & $657^{* * *}$ & $12 \cdot 1^{* * *}$ \\
\hline & & & & $13 \cdot 3$ & 1.5 & 22.0 & $52 \cdot 8$ & 0.52 \\
\hline
\end{tabular}

Values significantly different from values for birds with FLKS (diet A) $* P<0.05, * * P<0.01 * * * P<0.001$.

significant (Table 2). These criteria were also significantly increased when diet A was supplemented with tallow or biotin. Since pool sizes and synthesis rates of glucose were decreased the half-time of glucose in plasma tended to remain fairly constant, but in Expt 1 there was a significant difference $(P<0.05)$ between birds given diets $\mathrm{A}$ and $\mathrm{B}$ and starved for either 8 or $18 \mathrm{~h}$, while in Expt 2 there was a highly significant reduction $(P<0.001)$ in half-time of glucose in birds when diet A was supplemented with biotin.

\section{DISCUSSION}

The theoretical and practical aspects of using $\left[{ }^{3} \mathrm{H}\right]$ glucose for the measurement of glucose metabolism have been discussed extensively for sheep (Judson \& Leng, 1972) and rats (Katz \& Dunn, 1967). The principles established apply equally to studies in other species (Katz, Rostami \& Dunn, 1974). In birds that are starved for 8 or $18 \mathrm{~h}$ gluconeogenesis must supply all the available glucose since the absorption of nutrients from the digestive tract will be low. The transit time of food through the digestive tract in this age of broiler is about 3-4 h (Aylott, Vestal, Stephens \& Turk, 1968) and glycogen stores are not of a sufficient size to supply the glucose requirements over this period (Balnave \& Pearce, 1976). The use of $\left[2-{ }^{3} \mathrm{H}\right]$ glucose ensures that the quantitative estimate of glucose passing through 
the glucose pool is close to the total amount since there can be little recycling of tracer. Preliminary studies in which a number of samples over a long time period were taken indicated that first order kinetics apply to the isotope dilution in chickens following injections of $\left[2-{ }^{3} \mathrm{H}\right]$ glucose. This is supported theoretically since the tritium is lost from the glucose molecule early in its metabolism and enters the large hydrogen pool in body water. The extensive dilution of radioactivity in water effectively reduces recycling of tritium to negligible quantities (see Judson \& Leng, 1972; Katz et al. 1974). This is indicated by the results given in Fig. 1 where single exponential functions describe the isotope dilution results. Thus, if it is assumed that most of the plasma glucose arises by gluconeogenesis and that the isotope dilution technique measures the amount of glucose actually passing through the glucose pool, this technique estimates total gluconeogenesis rate.

In these studies, comparisons have been made of dynamic aspects of glucose metabolism in young birds maintained on a diet that induces FLKS or on a diet on which the syndrome is not observed (Expt 1). The results from the initial study (in which $37 \%$ of the birds died from FLKS $18 \mathrm{~h}$ after cessation of feeding diet A but only $7 \%$ died on diet B after the same period without food) indicate that there are marked differences in glucose metabolism between the two groups. The birds on diet B as compared with those on diet $\mathrm{A}$ had approximately double the glucose synthesis rate in the post-absorptive state (Table 2). Increasing the period without food from 8 or $18 \mathrm{~h}$ had apparently little effect on the rate of glucose synthesis. This may indicate that the glucose synthesis rate compatible with life or the minimum glucose requirements for essential functions, such as a supply of substrates for nervous tissues or blood cells (see Cahill \& Owen, 1967), is approximately 10-15 mg/min per $\mathrm{kg}^{0 \cdot 75}$.

The difference in glucose synthesis rates in fasted birds on different diets could be due to a number of factors in the diet, since on the 'FLKS-inducing' diet giving tallow for $2 \mathrm{~d}$ before fasting prevented the reduction in gluconeogenesis. In Expt 2 comparisons were made within a diet using supplements of tallow and biotin (Table 3). With both supplements the reduction in glucose synthesis rates was prevented and no deaths occurred, whereas without supplementation $20 \%$ of the birds died (Table 1 ).

A low rate of gluconeogenesis may be due to a failure to mobilize body reserves of precursors, such as glycerol from adipose tissue lipids and amino acids from body proteins, or be due to a decreased ability to synthesize glucose, or both. The low levels of key enzymes of glucogenesis in birds with FLKS compared with birds without the symptoms on the same diet or the same diet supplemented with tallow or biotin (Balnave et al. 1976; Johnson et al. 1976) indicate that the rate of glucose synthesis is lowered due to a lower enzyme activity in affected birds. This is supported by the fact that biotin supplementation significantly decreased the half-time of glucose in plasma (Table 3).

These studies provide strong evidence that a reduced availability of glucose for essential functions may be the main cause of death, since birds on the 'FLKS-inducing' diet but not showing symptoms had higher glucose synthesis rates than similarly fed birds suffering from the syndrome. In addition, both the two diverse dietary manipulations (i.e. supplementation with tallow or biotin) increased the rate of gluconeogenesis in the post-absorptive state. Since both treatments were effective in preventing deaths this supports the hypothesis that glucose deficiency in starvation is the prime reason for mortality and under applied conditions birds even on high carbohydrate diets lose their appetite and become lethargic before death from FLKS (Balnave \& Pearce, 1976).

In order for the young bird to meet its energy and glucose requirements during starvation glycogen is mobilized initially. However, glycogen reserves are small and subsequent mobilization of other body reserves, such as lipids and proteins which also supply glucose precursors, soon occurs. A reduced rate of glucose synthesis resulting from a reduction in 
the activity of key enzymes of gluconeogenesis at a time when increased mobilization of body reserves is occurring will result in an excess of substrates in blood. One way of disposing of these is by increased lipogenesis in the liver which becomes infiltrated with fat. The liver is the primary site of lipogenesis in birds (Goodridge \& Ball, 1967; Leveille, O'Hea \& Chakrabarty, 1968) and increased lipogenic enzyme activity is not observed in kidney and adipose tissue in FLKS-affected birds (Balnave \& Pearce, 1976). Johnson et al. (1976) have suggested that in birds affected by FLKS the reduced rate of gluconeogenesis that occurs is the result of a marginal availability of biotin and priority utilization of biotin by the lipogenic enzyme acetyl CoA carboxylase, the activity of which is increased (Johnson et al. 1976). Therefore, feeding tallow and biotin to maintain the activity of the gluconeogenic enzymes at a high level by either depressing lipogenic activity or supplying additional biotin respectively helps maintain glucose supply for essential functions and prevents the development of FLKS.

We are indebted to the Australian Chicken Meat Research Committee and the University of New England Research Grant for financial support for this programme. DB was a Visiting Research Fellow supported by funds from the Australian Chicken Meat Research Committee and the Council of Egg Marketing Authorities of Australia.

\section{REFERENCES}

Aylott, M. V., Vestal, O. H., Stephens, J. F. \& Turk, D. E. (1968). Poult. Sci. 47, 900.

Balnave, D., Cumming, R. B. \& Sutherland, T. M. (1976). Proc. Aust. Biochem. Soc. 9, 69.

Balnave, D. \& Pearce, J. (1976). Br. Poult. Sci. 17, 627.

Bannister, D. W. (1976). Biochem. J. 156, 167.

Bannister, D. W., Evans, A. J. \& Whitehead, C. C. (1975). Res. vet. Sci. 18, 149.

Cahill, G. F. \& Owen, O. E. (1967). In Carbohydrate metabolism and its Disorders (F. Dickens, P. J. Randle \& W. J. Whelan, editors), p. 497. New York: Academic Press.

Evans, A. J. \& Bannister, D. W. (1974). Wld's Poult. Sci. J. 30, 231.

Goodridge, A. G. \& Ball, E. G. (1967). Am. J. Physiol. 213, 245.

Huggett, A. St. G. \& Nixon, D. A. (1957). Biochem. J. 66, $12 P$.

Johnson, A. R., Hood, R. L., Pearson, J. A. \& Fogerty, A. C. (1976). Proc. Nutr. Soc. 35, 129 A.

Jones, G. B. (1965). Analyt. Biochem. 12, 249.

Judson, G. J. \& Leng, R. A. (1972). Aust. J. biol. Sci. 25, 1313.

Katz, J. \& Dunn, A. (1967). Biochemistry, Easton 6, 1.

Katz, J., Rostami, H. \& Dunn, A. (1974). Biochem. J. 142, 161.

Leng, R. A. (1970). Adv. Vet. Sci. 14, 209.

Leveille, G. A., O'Hea, E. K. \& Chakrabarty, K. (1968). Proc. Soc. exptl Biol. Med. 128, 398.

Payne, C. G., Gilchrist, P., Pearson, J. A. \& Hemsley, L. A. (1974). Br. Poult. Sci. 15, 489.

Whitehead, C. C. (1975). Res. vet. Sci. 18, 32.

Whitehead, C. C., Bannister, D. W., Wight, P. A. L. \& Weiser, H. (1974). Proc. 15th Wld's Poult. Cong. New Orleans, U.S.A., p. 70. 